\title{
Who may benefit most from future vitamin $D$ intervention trials: do not forget patients on continuous renal replacement therapy
}

\author{
Patrick M. Honore*, Aude Mugisha, Luc Kugener, Sebastien Redant, Rachid Attou, Andrea Gallerani and \\ David De Bels
}

We read with great interest the recent paper by Martucci et al. who concluded that high-dose vitamin D3 supplementation was associated with a reduction in 28-day mortality in a mixed population of critically ill adults with vitamin D deficiency [1]. Their analysis also attempted to identify who may benefit the most from future vitamin $\mathrm{D}$ intervention trials [1]. We would like to make some comments. In their paper, Martucci et al. did not include data regarding patients with acute kidney injury (AKI) needing renal replacement therapy (RRT) within the critically ill population they studied [1].

25-Hydroxyvitamin D has a molecular weight of 400 $\mathrm{Da}$ and thus should be easily removed by dialysis [2]. However, most of 25-hydroxyvitamin D is bound to vitamin D-binding protein, which has a molecular weight of $10 \mathrm{kDa}$ and needs convection to be removed [3]. Convection, the main modality used in continuous renal replacement therapy (CRRT), can drastically reduce levels of both 25-hydroxyvitamin D and vitamin D-binding protein $[3,4]$. Uhlin et al. found that the use of convection was very deleterious for 25-hydroxyvitamin D levels, with a significant reduction in 25-hydroxyvitamin D levels following the switch to online hemodiafiltration [5]. We agree with the authors that critically ill patients would benefit from vitamin $\mathrm{D}$ intervention trials, and given the significant loss of vitamin $\mathrm{D}$ in patients undergoing RRT, we believe this group of patients in particular should be a focus of further study. Studying these patients is made complicated by techniquerelated differences (type and frequency of RRT, type of membrane used, etc.) and individual patient pharmacokinetic variations (changes in volume of distribution, degree of protein binding, residual renal function, intestinal absorption of vitamin D, etc.). Perhaps the most pragmatic approach in a future study would be to give a loading dose of vitamin $\mathrm{D}$, similar to that of the VITdAL-ICU study [1], and then monitor blood concentrations, like we do for antimicrobials, to guide further dosing requirements.

\section{Authors' response}

Gennaro Martucci, Dayre McNally, Dhruv Parekh, Karin Amrein

Dear Editor,

We read with great interest the letter by Honore and collaborators on the supplementation of vitamin D in critically ill patients undergoing continuous renal

This comment refers to the article available at https://doi.org/10.1186/ s13054-019-2472-z.

* Correspondence: Patrick.Honore@CHU-Brugmann.be

ICU Department, Centre Hospitalier Universitaire Brugmann-Brugmann University Hospital, Place Van Gehuchtenplein, 4, 1020 Brussels, Belgium replacement therapy (CRRT). We agree with the approach suggested for several reasons: First, from the methodological point of view, the accumulation of adequate data on basic science, including observational data on pharmacodynamics and pharmacokinetics applied in clinical practice, should be mandatory to better target the population that would benefit more from a specific intervention tested in an RCT [6-8]. Second, from the clinical side, this observation is highly relevant, 
since in our post hoc analysis chronic kidney disease was associated with a reduction of the survival benefit in the treatment group.

Unfortunately, we are unable to provide the requested data as the VITDAL-ICU Trial recruited from 2010 to 2012, and though patients on dialysis were not excluded, they were only a small minority of the study population. Also, at the time of the trial, CRRT was not as frequently used as today, and data on CRRT were not recorded systematically [9].

We would like to stress that clinicians administering vitamin $\mathrm{D}$ should be aware of the factors that may contribute to acute changes in vitamin D levels [10]. Both for changes in volume distribution and for cartridge absorption and filtration, the level of vitamin D is lower in critically ill patients on CRRT, and the same can be hypothesized in the case of supplementation [11]. In fact, it is clear that CRRT is able to reduce the plasma level of proteins, foremost albumin, but also vitamin D-binding protein with its ligand vitamin D [12]. This fact alone should be reason enough to prompt higher doses of vitamin D supplementation to be effective, though there are no data to support this hypothesis.

Indeed, moving forward from the VITDAL study and ideally continuing it, the VITDALIZE trial, a European multicenter RCT focused on vitamin D supplementation in patients with severe vitamin D deficiency, will also consider patients with ongoing CRRT, and will likely give an answer to both questions: variation of vitamin D plasma levels during CRRT, and the ability of high doses of cholecalciferol in reducing mortality [13].

\section{Abbreviations}

AKI: Acute kidney injury; RRT: Renal replacement therapy; CRRT: Continuous renal replacement therapy

\section{Acknowledgements}

We would like to thank Dr. Melissa Jackson for critical review of the manuscript.

\section{Authors' contributions}

$\mathrm{PMH}, \mathrm{SR}$, and DDB designed the paper. All authors participated in drafting and reviewing. The authors read and approved the final version of the manuscript.

\section{Funding}

None.

\section{Availability of data and materials}

Not applicable.
Received: 15 March 2020 Accepted: 21 April 2020

Published online: 28 April 2020

\section{References}

1. Martucci G, McNally D, Parekh D, Zajic P, Tuzzolino F, Arcadipane A, Christopher KB, Dobnig H, Amrein K. Trying to identify who may benefit most from future vitamin $D$ intervention trials: a post hoc analysis from the VITDAL-ICU study excluding the early deaths. Crit Care. 2019;23(1):200. https://doi.org/10.1186/s13054-019-2472-z..

2. Honoré PM, De Waele E, Jacobs R, Mattens $S$, Rose T, Joannes-Boyau O, De Regt J, Verfaillie L, Van Gorp V, Boer W, Collin V, Spapen HD. Nutritional and metabolic alterations during continuous renal replacement therapy. Blood Purif. 2013;35(4):279-84. https://doi.org/10.1159/000350610 Epub 2013 May 8. Review..

3. Honoré PM, De Bels D, Spapen HD. An update on membranes and cartridges for extracorporeal blood purification in sepsis and septic shock. Curr Opin Crit Care. 2018;24(6):463-8. https://doi.org/10.1097/MCC. 0000000000000542 Review.

4. Cavalier E, Torres PU, Dubois BE, Smelten N, Pottel H, Krzesinski JM, Delanaye P. Impact of the type of dialysis membranes on the circulating concentration of markers of vitamin D metabolism. Int J Artif Organs. 2017; 40(2):43-7. https://doi.org/10.5301/ijao.5000565 Epub 2017 Feb 18.

5. Uhlin F, Magnusson P, Larsson TE, Fernström A. In the backwater of convective dialysis: decreased 25-hydroxyvitamin D levels following the switch to online hemodiafiltration. Clin Nephrol. 2015;83(6):315-21. https:// doi.org/10.5414/CN108468

6. Vincent $J \mathrm{~L}$, Marini JJ, Pesenti A. Do trials that report a neutral or negative treatment effect improve the care of critically ill patients? No. Intensive Care Med. 2018:44(11):1989-91..

7. Martucci G, McNally D, Parekh D, Zajic P, Tuzzolino F, Arcadipane A, Christopher KB, Dobnig H, Amrein K. Trying to identify who may benefit most from future vitamin $D$ intervention trials: a post hoc analysis from the VITDAL-ICU study excluding the early deaths. Crit Care (London, England). 2019;23(1):200..

8. Amrein K, Martucci G, McNally JD, et al. Clin Nutr (Edinburgh, Scotland). 2017;36(6):1729-30.

9. Amrein K, Schnedl C, Holl A, Riedl R, Christopher KB, Pachler C, Urbanic Purkart T, Waltensdorfer A, Munch A, Warnkross $H$, et al. Effect of high-dose vitamin D3 on hospital length of stay in critically ill patients with vitamin D deficiency: the VITdAL-ICU randomized clinical trial. JAMA. 2014;312(15): 1520-30..

10. Zajic P, Heschl S, Schörghuber M, Srekl-Filzmaier P, Stojakovic T, Weixler V, Zelzer S, Amrein K. Vitamin D assessment in perioperative medicine and critical care: A prospective observational pilot study. Wien Klin Wochenschr. 2019. https://doi.org/10.1007/s00508-019-01584-x. [Epub ahead of print].

11. Amrein $\mathrm{K}$, Scherkl M, Hoffmann M, Neuwersch-Sommeregger S, Kostenberger M, Tmava Berisha A, Martucci G, Pilz S, Malle O. Vitamin D deficiency 2.0: an update on the current status worldwide. Eur J Clin Nutr. 2020. https://doi.org/10.1038/s41430-020-0558-y. [Epub ahead of print].

12. Lefler DM, Pafford RG, Black NA, Raymond JR, Arthur JM. Identification of proteins in slow continuous ultrafiltrate by reversed-phase chromatography and proteomics. J Proteome Res. 2004;3(6):1254-60..

13. Amrein K, Parekh D, Westphal S, Preiser JC, Berghold A, Riedl R, Eller P, Schellongowski P, Thickett D, Meybohm P. Effect of high-dose vitamin D3 on 28-day mortality in adult critically ill patients with severe vitamin D deficiency: a study protocol of a multicentre, placebo-controlled doubleblind phase III RCT (the VITDALIZE study). BMJ Open. 2019;9(11):e031083..

\section{Publisher's Note}

Springer Nature remains neutral with regard to jurisdictional claims in published maps and institutional affiliations.

Ethics approval and consent to participate

Not applicable.

Consent for publication

Not applicable. 